\title{
Migration and Migrant Entrepreneurship in a German-Polish border region
}

Social sciences are interested in ethnic entrepreneurship as a chance for migrants to (better) integrate into the host labour market, and in consequence into a host society. The multidimensional models capture a wide range of factors at the bottom of the economic behaviour of migrant entrepreneurs, and they increasingly consider that migrants might profit in business from sustaing their social ties with the country of their origin. Looking at Polish migrant entrepreneurs in eastern German regions bordering to Poland we plead for a relational perspective which considers migrants' business activities in relation to the patterns of trans-border residential mobility and complex social and economic transformations in Polish and German border regions.

Keywords: ethnic entrepreneurship; German-Polish border region; immigrants; residential mobility; economic transformation.

\section{Introduction}

The process of social and economic integration and the persisting inequalities between the regions within the European Union constitute a unique context for development of migrant employment patterns. In this context, migrant entrepreneurship in a border region between Germany and Poland is particularly intriguing and important for both the social sciences as well as decision-makers and people living in both countries. In recent years, business activities of Polish citizens in Germany have become of interest to the general public. The scarce, episodic and

\footnotetext{
${ }^{1}$ Corresponding author: Magdalena Nowicka, magdalena.nowicka@hu-berlin.de
} 
politically driven public debate focuses on the potential misuse of self-employment by Polish migrants competing for work with German citizens and the supposed negative economic and social consequences of so-called 'wage dumping' in processing industries. However, social scientific evidence on the phenomenon of Polish migrant entrepreneurship in the German region bordering Poland remains fragmentary and incomplete.

Thereby, the number of migrants from Poland living in Germany is steadily growing. Between 1996 and 2014, Poland was the main country of origin of new migrants in Germany. ${ }^{2}$ Poles constitute the second-largest single national migrant group in this country ( $9.9 \%$ of all migrants). Their number is estimated at approximately 1.7 million. More than two-thirds of them are first generation migrants (Migrationsbericht 2015). About 10\% of all Poles live in former East Germany. Of interest to our contribution are three federal states: Berlin, Brandenburg, and Mecklenburg Western Pomerania. ${ }^{3}$ In Berlin alone, some 107,000 Poles are registered. At the end of 2016, about 22,000 Poles lived in Brandenburg (four times as many as in 2003, and twice as many as in 2014), and about 10,700 in Mecklenburg Western Pomerania (almost five times as many as in 2004). ${ }^{4}$ Recently, various authors have pointed to the relevance of new Polish migrants and their entrepreneurial activities for the localities in this region ( Lada and Segeš Frelak, 2012). However, the information on migration from Poland to Germany at the local and regional levels is incomplete; we thus miss a full picture of different forms of migration, for example commuting or transnational movements. This contribution relies on the available statistical data to put light on the size and characteristics of Polish migrant entrepreneurship. Our aim is to show the relative importance of Polish migrant entrepreneurship in the region, provide information on the sectoral distribution of businesses run by Poles, and to consider the larger context in which Polish migrants become entrepreneurs.

In the following, we first sketch the contours of theoretical engagements with migrant entrepreneurs. We conclude this review pointing to the open questions in research in this field, in particular in the context of trans-border migration in a European border region. We proceed presenting the demographic and economic characteristics of the German-Polish region, and how they facilitate migration. We then move on to discuss the volume and forms of Polish migrant entrepreneurship in Germany. We focus on a comparison between Berlin and Brandenburg as two interdependent spaces.

In the concluding section, we stress the need for a relational perspective that considers interlinked processes and transformation on both sides of the nation-state

\footnotetext{
${ }^{2}$ In 2015, migrants from Syria and Romania outnumbered migrants from Poland for the first time.

${ }^{3}$ In its southern part, the German-Polish border divides Silesia and Saxony which are not considered in our research.

${ }^{4}$ Central Foreigner Register data obtained from: Amt für Statistik Berlin-Brandenburg (2016), Statistisches Amt Mecklenburg-Vorpommern (2016).
} 
border. Following this strategy, we are sensitive to the meso-level of the observed processes. For us it means zooming in to capture how the asymmetrical developments in the parts of the region create new time-and-place specific opportunities (Waldinger et al., 2006a; Light and Rosenstein, 1995) for migrant entrepreneurs. We argue that while it is true that shrinking and expanding markets can be equally open to migrant entrepreneurs, the picture would not be complete without a transnational lens.

\section{Migrant entrepreneurship through the lens of theory}

Social sciences usually consider ethnic entrepreneurship from the perspective of migrants' integration in the host community. A scientific debate initiated by North American sociologists (Bonacich, 1973) has been relatively lately picked up in Europe (Clark and Drinkwater, 2000; Kloosterman and Rath, 2001). The key question put forward first was why migrants - compared to indigenous people indicate much higher self-employment rates. Sociological explanatory models in the United States were primarily concerned with the importance of individual skills and individual characteristics in relation to surrounding conditions. Central to these explanations was the focus on how certain human capital - skills, education, language competence - enables migrants to find employment outside or inside an ethnic economy (Nee and Sanders, 2001; Sanders and Nee, 1996). These models drew on micro-economical and rational choice approaches and were criticized for overlooking constraints to entrepreneurship activities resulting from migrants' (ethnic) group belonging. Another group of theories, including the middleman minority theory (Bonacich, 1973: 38), the enclave theory (Portes and Bach, 1985) and other discriminatory models, conceptualized the path to independence as an outcome of social exclusion. Thus, these theories referred to the accessibility and use of resources available to each group and to their marginal position in the society. Having only deficient access to resources, members of these groups reach for ethnic capital. Ethnic capital should be understood as social capital: social networks enabling access to resources both material - money, spaces, workforce, customers (Light and Rosenstein, 1995; Bates, 1998) - and non-material - trust, solidarity, language, information (van Delft et al., 2000; Light, 1987) - within their own ethnic group (Light and Gold, 2008; Bates, 1998; Granovetter, 1995; Borjas, 1990; Nawojczyk, 2009). In turn, migrant ethnic entrepreneurs often remain bound in their activities to their own ethnic group, for the same ethnic group is also the best customer for the services and goods they provide. Yet, neither the ethnic enclave thesis nor the middleman minority model seems to provide a satisfactory explanation for the development of Polish migrant entrepreneurship in Germany. Poles do not create ethnic enclaves in Germany; Polish migrants constitute an internally 
highly differentiated group; and employment rates of Poles in Germany do not significantly differ from those for native Germans. The claim of a marginal position as a group thus does not find sufficient support in the existing data.

Since the 1990s, there has been a fair consensus that structural factors are as equally important as individual migrants' decision-making on self-employment. To this day, most of the research on ethnic entrepreneurship applies to an interaction thesis formulated by Waldinger, Aldrich and Ward (2006b). This multidimensional model captures a number of factors and processes at the bottom of the economic behaviour of migrant populations. Advancing this model, Kloosterman and Rath (2001) as well as Razin (2002) pointed to the social embeddedness of entrepreneurial activities of migrants in local political and institutional contexts. More recent research on ethnic entrepreneurship also considers the role of social and economic transformations related to globalization; for example, it demonstrates how migrants use cheap transportation and online networks to gain relative independence from localized (and nationalized) contexts (Pries, 2000). In addition, various authors stress that the nature and forms of migrant self-employment are changing along with the new, temporary, incomplete, circular and transnational patterns of international migration (Glick Schiller et al., 1995; Light, 2007; Goebel and Pries, 2006; Portes, 2003). In turn, a new type of "transnational entrepreneur" emerges. Such entrepreneurs are embedded in social and economic networks in both their countries of origin and residence (Portes et al., 2002; Drori et al., 2009). For the purposes of examining Polish self-employed workers in Germany, this lens is most appropriate, for numerous studies demonstrate strong transnational ties maintained by Polish migrants (Glorius, 2007; Nowicka, 2007; Miera, 2008; Palenga-Möllenbeck, 2014). At the same time, there are no empirical studies specifically on Polish migrant entrepreneurs to shed light on how this group makes use of resources embedded in localities on both sides of the nation-state border to advance their economic activities, nor how processes at both sides of the border influence their strategies.

In the context of Polish migration, transnationalism includes transformations related to the process of European integration. The accession of Poland to the European Union in May 2004, preceded by a long phase of political and economic changes, has created a unique set of conditions for migration and entrepreneurial activities of Poles in the border region. The European integration process transforms the meaning of the nation-state border (Łada and Segeš Frelak, 2012). Thereby, mobility across the German-Polish border developed continuously into a stable migration system. The European integration process also transforms the economic conditions in the border region on both sides of the border, through European Union programs and funds. 


\section{Polish-German border region: uneven developments}

Border regions within the European Union are frequently considered laboratories of European integration (Opiłowska, 2015b), due to the daily cross-border activities of ordinary citizens. Often located far away from the major national centres and not subject to mainstream national socio-economic politics, intra-European border regions are subject to the EU's policies, as a means for overcoming state divisions on the way to a united Europe (van Houtum, 2000). This unique position offers border regions new and diverse growth opportunities through various forms of regional cooperation, with the support of EU funds (Błachut et al., 2015). Further, the distinct character of border regions relates to the shifting meaning of the state border. In practice, borders serve simultaneously as barriers, bridges, resources and symbols of identity; to which extent the borders within the EU, such as the German-Polish border, are rather distortions or linkages, is an effect of implementation of provisions such as the Single Market, but also of the quality of material infrastructures such as roads, which enable mobility (Anderson and O'Dowd, 1999). EU programs such as INTERREG help stimulate regional crossborder networking, for example by co-funding transportation (O'Dowd, 2002). While many studies could prove negative border effects - for example for trade, or traffic that decreases because of a border (van Houtum, 2000), it is also true that disparate levels of economic development, and differing legal systems on both sides of the border create unique opportunities for entrepreneurs. Economic disparities, incompatibility of administrative structures and asymmetry in the perception of neighbours could be important factors changing the forms and scope of entrepreneurial activities of people in the region (Krätke, 1999).

The border region of interest to us is the Oder-Neisse border region, with parts of two voivodeships on each side of the border: West Pomeranian (Zachodniopomorskie) and Lubusz (Lubuskie) in Poland, and Mecklenburg Western Pomerania (Mecklenburg-Vorpommern) and Brandenburg in Germany, as well as the city-state Berlin. Until 1945, today's Polish West Pomeranian and Lubusz voivodships were part of the German provinces of Pomerania and Brandenburg; in 1995, these regions became inner EU border regions (parts of Euroregion Neisse and Euroregion Pomerania); in 2004, Poland accessed the European Union; in 2007, the German-Polish border became the Schengen Zone inner border. It would exceed the scope of this paper to give a detailed account of the history of the region. ${ }^{5}$ Nevertheless, it is worth noting that the historical connections, for example between Berlin and Szczecin (facilitated by the overland railway routes from 1843, or the waterway constructed in 1914) still shape the migration patterns and entrepreneurial activities in this border region today.

\footnotetext{
${ }^{5}$ Interested readers may find information in Piskorski (1999) and Inachin (2008).
} 
Following the establishment of a new state border in 1945, both sides of the region became peripheral to their nation-states. Until today, the German and Polish sides share similar economic conditions, still largely shaped by socialist and postsocialist politics (Fritsch et al., 2015): they are mostly rural and scarcely populated (Reichert-Schick, 2010) and both were affected by the "shock" neoliberal reforms of the 1990s that led to a decrease in industrial production and an increase in unemployment.

\subsection{Demographic characteristics of the region}

The four voivodships are regionally differentiated, so that the analyses should consider the level of districts rather than the complete voivodships ${ }^{6}$. For example, while population density in Lubusz is 73 persons $/ \mathrm{km}^{2}$ (second smallest in Poland), the districts bordering Germany (gryfiński, słubicki, krośnieński, gorzowski, sulęciński) are even less populated (density of 30-59 persons $/ \mathrm{km}^{2}$ ). While Brandenburg is more densely populated, with 87 persons $/ \mathrm{km}^{2}$ it is much below the average for Germany ( 237 persons $/ \mathrm{km}^{2}$ ). District Uckermark bordering Poland is one of Brandenburg's least densely inhabited (39 persons $\left./ \mathrm{km}^{2}\right)$. Mecklenburg Western Pomerania is Germany's least densely populated region (70 persons $\left./ \mathrm{km}^{2}\right)^{7}$

Eastern German states were strongly affected by outgoing migration to the West of Germany. The recent positive population growth rates $(0.8 \%$ in 2016 in Mecklenburg Western Pomerania and 1.3\% in 2015 in Brandenburg) are due to new domestic and international migration (Paffhausen, 2016). In Poland, the population in West Pomeranian and Lubusz has decreased slightly over the years due to the decreasing natural growth rate of population in these regions $(-0.7 \%$ in Lubusz and $-1.3 \%$ in West Pomeranian, as of 2015). The discrepancy between the 2011-census and register data point to temporary, commuting and transnational migration from Poland, for people do not de-register their property while living and working abroad. Importantly, between 2002 and 2011 (census years), the number of international outgoing migrants increased four times. Further, the number of temporal migrants has increased. According to the last census in 2011, almost 70,000 inhabitants of Lubusz and 107,491 of West Pomeranian lived abroad. Germany was the second main target of migration, after the UK (Matkowska, 2013; UStat, 2014).

Importantly, the age structure of the region points towards current and future challenges. The ongoing exodus of young people to the western part of Germany

${ }^{6}$ This constitutes a serious challenge to the research due to poor availability of selected data at the district level.

${ }^{7}$ All data from regional statistical offices https://szczecin.stat.gov.pl; http://zielonagora.stat.gov. pl/; https://www.statistik-berlin-brandenburg.de; https://www.laiv-mv.de/static. 
negatively affects the former eastern federal states; in turn, practically all localities in this region struggle with ageing of their populations, and thus decreasing workforce and employment rates (Vogler-Ludwig et al., 2014). Various studies for Lubusz and West Pomeranian voivodships forecast a decrease of population until 2050, in particular in working age, and ageing of the population in general, thereby the average age is lowest in Lubusz (average age 39.5, compared to 40.8 in West Pomeranian, 46.5 in Mecklenburg Western Pomerania, and 46.8 in Brandenburg). ${ }^{8}$

Within these regions, two cities stand out: Szczecin is, with 380,000 people, the largest regional centre and seventh biggest city in Poland, while Berlin, located in the heart of Brandenburg (though administratively a separate federal state), has almost 3.5 million inhabitants, almost as many as the two border regions together. These two cities have tremendous importance for the surrounding regions. Berlin is a booming city, with its population growing steadily and fast. Between 2010 and 2016, it increased by $8.4 \%$ (Niemann-Ahrendt, 2017). The sharp increase in Berlin's population is related to international immigration (in particular recent refugees); among international migrants, Poles remain an important group with about 4,000 new registrations in Berlin each year. While fewer people move to Berlin from its direct surroundings, or other parts of former East Germany (Niemann-Ahrendt, 2017), Berlin is a strong regional economic centre concentrating activities of advanced producer services and new creative industries.

\subsection{Economic situation in the region}

Despite the similarities between the voivodships in terms of their typical peripheral demographic characteristics, these regions differ substantially in terms of their economic conditions and potentials. Both Brandenburg and Mecklenburg Western Pomerania belong to the less-developed regions of the European Union. Both are below the German average on most key indicators, such as available income per capita and unemployment rate. However, the unemployment rate is steadily decreasing (by half since 2007), and the gap between the national average and the region is closing. Brandenburg profits from Berlin's economic development (for example, the available income per capital is now higher in Brandenburg than in Berlin, although still $88 \%$ of the German average) (Amt für Statistik Berlin-Brandenburg, 2017). Brandenburg's economic growth of $1.7 \%$ in 2016 is close to the national average, while Mecklenburg Western Pomerania remains the second slowest developing region in Germany. Despite this positive trend, the forecasts show that both federal states will continue to lag behind the rest of Germany in terms of their economic potential (Vogler-Ludwig et al., 2014).

${ }^{8}$ Data from statistical yearbooks 2017 for Lubusz and West Pomeranian voivodships. 
Berlin remains an exception in the region, with 2.7\% GDP growth in 2016 but high unemployment.

Regional disparities characterize the Polish side of the region as well. West Pomeranian was Poland's third-fastest growing regional economy with 5.7\% GDP growth in 2015, compared to the national average $4.6 \%$. In terms of GDP per capital, West Pomeranian stabilized at rank 8 of 16 Polish voivodships and can no longer be considered a national periphery. While unemployment in West Pomeranian voivodship remains high, it is decreasing faster than the national average. Thereby, Szczecin is the motor of these positive developments in the region, with low unemployment and a high rate of foreign direct investments (mostly from Scandinavia). In comparison, employment in industry in Lubusz is higher than the national average, but is much lower in services. The region lacks large and strong agglomerations and large innovative companies but is characterized by high natural and tourist values. The unemployment rate is rapidly decreasing, and the last two years have witnessed particularly fast growth of the region's economy.

\subsection{Migration patterns}

The topography of local disparities is of key importance when we consider which factors impact migration and migrant self-employment in the region. It is often Eastern Germany which profits from a relative boom in nearby Poland. Mecklenburg Western Pomerania, with weak economic potential, is adjacent to the economically well-developing West Pomeranian province (Maack et al., 2004). Brandenburg is adjacent to the comparatively poorly developing Lubusz province, but profits from Berlin. According to conventional migration theory, there are strong incentives for (return) migration from Germany to Poland, but this thesis does not find confirmation in the available data.

Interestingly, the highest number of new migrants from Poland is registered in the part of the German side of the border region which is economically less developed and where inhabitants have low purchasing power: the VorpommernGreifswald district in Mecklenburg Western Pomerania. ${ }^{9}$ In Brandenburg, the town of Cottbus and the border town of Frankfurt (Oder) register the highest number of Polish citizens, followed by the Uckermark district south of Vorpommern-Greifswald, which is also one of the most structurally deficient districts in Brandenburg, characterized by high unemployment (12.4\%) and low purchasing power. ${ }^{10}$ If we

${ }^{9}$ IHK (Industry and Commerce Chamber) Neubrandenburg Statistik 2016 available from https://www.neubrandenburg.ihk.de/standortpolitik/konjunktur-und-statistik/statistik/.

${ }^{10}$ IHK (Industry and Commerce Chamber) Ostbrandenburg Statistik 2016, available from https://www.ihk-ostbrandenburg.de/produktmarken/Standortpolitik/Konjunktur---Statistik/Strukturdatenatlas-/3487426. 
zoom in even further, we see that the localities most popular among new migrants from Poland are either along the border or along the roads leading to Szczecin which suggests that transnational transport infrastructures matter for residential choices of Poles.

We believe that the asymmetrical pace of sectoral developments in the border region creates new patterns of push and pull factors for migration. One indicator which is rarely considered and yet in our view is of key importance is the development of local real estate markets. While some ten years ago low costs of living and high unemployment forced many Poles to commute to work in Germany on a daily basis, since 2007/2008 the rising real estate prices in some localities in Poland became an incentive for Poles to buy properties in nearby and much cheaper Mecklenburg Western Pomerania. For the equivalent of a two-room apartment in Szczecin, one could buy a terraced house in Mecklenburg Western Pomerania. This development is also an outcome of the past transnational forms of migration in the region; in particular returnees and transnational migrants invest money in real estate in Poland (Brzozowski, 2011), which they then rent. In Szczecin, for example, the increasing number of students (coming to the town also from Germany, see GUS, 2017), creates both new demand for housing and profits for those investing "migration money".

Although we lack exact data on cross-border mobility patterns in the region, we know that a comparatively large share of workers commutes from the Lubusz and Western Pomerania cross-border: these are $1.87 \%$ and $1.96 \%$, respectively. But we also observe the increasing mobility towards Poland: an estimated $0.5 \%$ commute from Brandenburg and Mecklenburg Western Pomerania to a neighbouring country (Eurostat, 2016). This is a new transnational pattern but we lack information on who the commuters from Germany to Poland are. While higher income levels, GDP per capita, and lower unemployment rate, compared to Poland, are strong incentives for economic migration from Poland to Germany, on the regional and local scale the particular demographic and economic situation paired with fast growth in Poland creates strong incentives for residential mobility to Germany and transnational form of living. Interviews in the field with real estate companies suggest that this form of residential mobility is progressing and expanding towards the south of Brandenburg, now encompassing not only the areas closest to Szczecin but also reaching the destinations bordering Lubusz voivodship. Current migrants from Poland are revitalizing local economies, offering services to both aging Germans and new Polish families settling in Germany. But Polish residents on the German side of the border region are no loss to the Polish economy, for they commute on regular basis to Poland, to visit families and friends and go shopping or to the cinema. Clearly, language plays a role in their daily practices, but this will not be a constraint to the next generation growing up bilingually. Potentially, this 
commuting form of migration for work and leisure to Poland could switch in the next generation to more stable migration to larger centres in Germany, rather than to return migration to Poland.

\section{Polish migrant entrepreneurs}

The development of Polish migrant entrepreneurship in Germany needs also to be considered in the context of labour market regulations and access to dependent employment for migrants from Poland in Germany, as well as in relation to the overall propensity to entrepreneurial behaviour in Poland and in Germany. Again, while discussing these aspects, we take a perspective acknowledging regional and local asymmetries and trends.

Although Poland joined the European Union on $1^{\text {st }}$ May 2004, the transitional restrictions on free movement of workers which Germany applied limited access for Polish citizens to the German labor market until May 2011. The effects on employment of both the Polish accession to the EU and the temporary restrictions are highly controversial. The migration statistics suggest that transitional restrictions did not limit the overall volume of migration from Poland to Germany; instead, the open access to the labor market in the UK, the Netherlands and Scandinavia increased migration on the side of a population which had not seriously considered migration as an option before (Nestorowicz et al., 2015). Instead of a re-direction

Self-employment 2005-2016, Polish migrants in Germany.

Graph 1 .

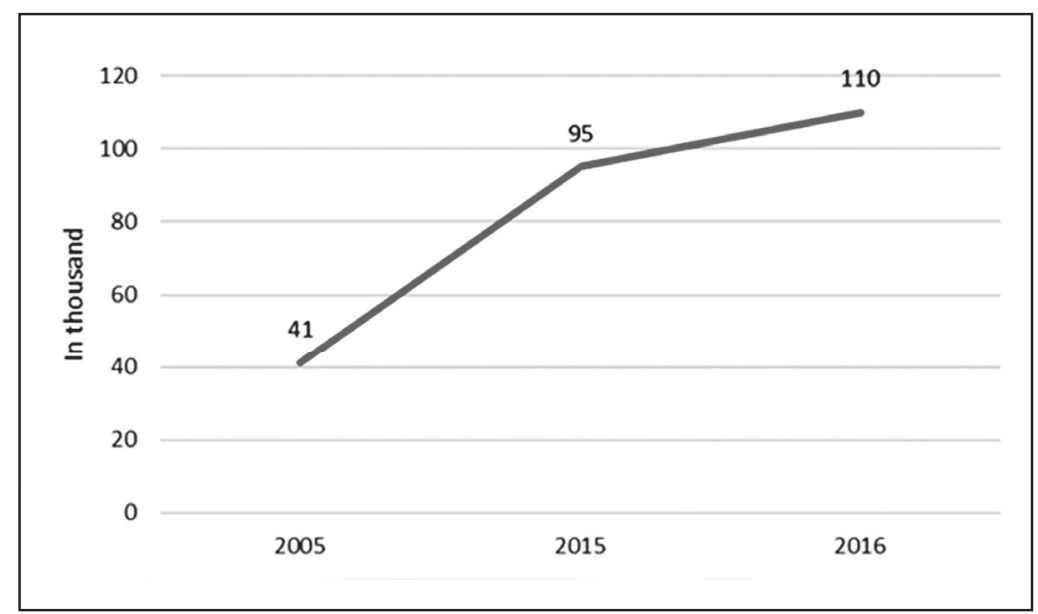

Source: Own presentation after R. Leicht et al. (2017) Gründungspotenziale von Menschen mit ausländischen Wurzeln: Entwicklungen, Erfolgsfaktoren, Hemmnisse. 
of flows to more liberal markets, the liberalization of access induced a new migration wave and a new type of migrant (young, well-educated, and from all regions of Poland). Also, as freedom of services and movement for residence was not restricted, it was possible for migrants to choose self-employment (to some extent fraudulent) or undeclared work in Germany also prior to 2011.

The available data from micro-censuses suggest that Polish migrants are the largest group among migrant entrepreneurs in Germany, outnumbering people coming from Turkey, who traditionally have had a high propensity towards selfemployment: 95,000 companies were registered in Germany in 2015 by people who immigrated from Poland (Leicht et al., 2017). Between 2005 and 2016, the number of companies registered in Germany by Polish migrants has more than doubled. This trend has not decreased since 2011, when the restrictions on access to the German labor market were abandoned (Leicht and Langhauser, 2014).

The few existing studies taking a regional perspective and using census data demonstrate that migrants in former East Germany are three times as likely to start up their own business as are migrants in former West Germany (Leicht et al., 2017). In Berlin, every fourth self-employed person is a migrant, even though migrants (refugees excluded) constitute roughly $14 \%$ of the city's population (Jost and Bogai, 2016). According to the Census data from 2011, some 15\% of all self-employed migrants in Berlin are from Poland, which is above the German average.

In this contribution we use data from business registries (Gewerberegister) to picture the entrepreneurial activities of Poles in Germany. A business registration (Gewerbeanzeige) is required whenever an independent commercial enterprise with fixed premises is newly established in a place. These data include companies (sole proprietorship companies [Einzelunternehmer]) but not people (one person could register more than one company). Also, these statistics reveal only the citizenship of the registering person, with no information on the person's migration history (thus excluding naturalized migrants from Poland).

Table 1 .

Start-up intensity, 2016.

\begin{tabular}{|l|c|c|c|}
\hline Citizenship/Region & Berlin & Brandenburg & $\begin{array}{c}\text { Mecklenburg Western } \\
\text { Pomerania }\end{array}$ \\
\hline German & 94 & 84 & 85 \\
\hline Foreign & 337 & 236 & 188 \\
\hline Polish & 1490 & 361 & 234 \\
\hline
\end{tabular}

Source: Gewerbeanzeigen in den Ländern, 2017; Ausländerstatistik. Own representation. 
The number of business registrations needs to be set in relation to the volume of migration, respectively the size of the migrant population in Germany. The indicator used here is the start-up intensity, which shows how many businesses are registered per 10.000 people aged $18-65$ (working age population ${ }^{11}$ ). Table 1 presents the overview for the three relevant regions in Germany. This data is comparable with the NUI-indicator which shows the start-up intensity 2016 for Germany to be $125.4 .^{12}$

\subsection{Polish migrant entrepreneurs in Brandenburg and Berlin}

Now we want to have a closer look at business registration statistics for Brandenburg and Berlin. We consider Brandenburg to be representative in terms of the economic and demographic conditions as well as the start-up intensity of Poles. At the same time, Brandenburg has a much longer border with Poland $(267 \mathrm{~km})$. For it surrounds the city of Berlin, it is an interesting case for comparison between rural and urban context of migrant entrepreneurship.

In Brandenburg, the number of registrations by Polish citizens has been rather stable over years but it is decreasing now (graph 3). 2015 and 2016 more closures than openings were registered but 2017 points to the growing economic activity in the region.

Graph 3 .

Total business registrations by Polish citizens in Brandenburg, 2010-2017.

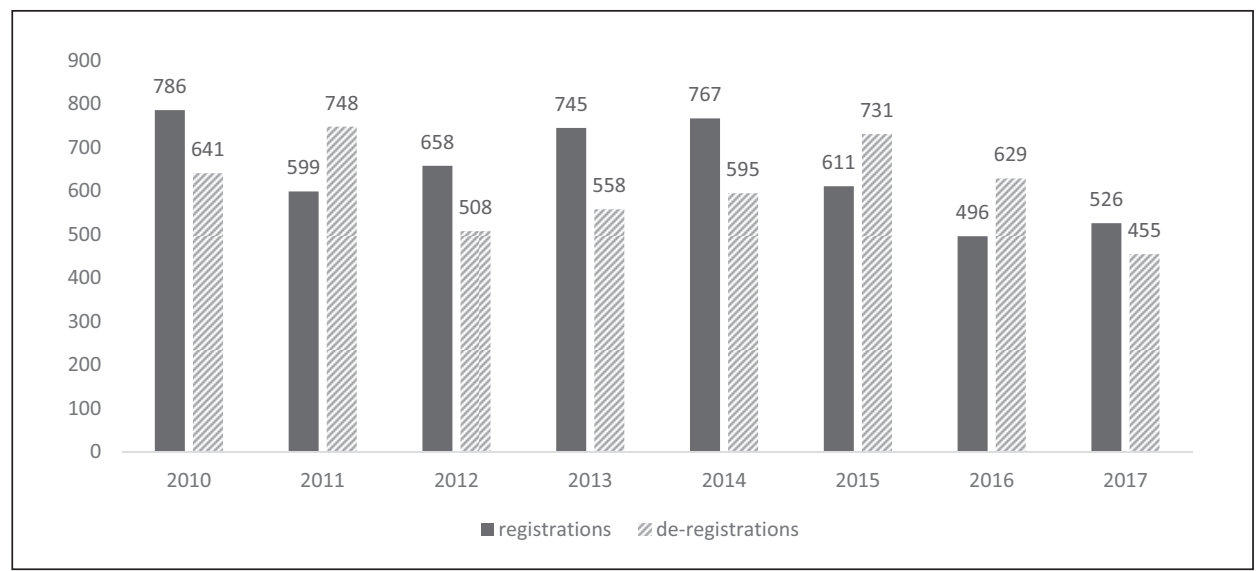

Source: Unternehmen und Arbeitsstätten. Gewerbeanzeigen in den Ländern 2010-2017, own representation.

${ }_{11}$ This indicator considers only "first generation migrants" with Polish citizenship, for the sake of comparability with the NUI-indicator.

${ }_{12}$ The NUI-Ranking is prepared yearly by IfM Bonn, see https://www.ifm-bonn.org/statistiken/ gruendungen-und-unternehmensschliessungen/. 
Considering the comparatively high start-up intensity, these absolute numbers are rather low. Also, when comparing to the development of the Polish population in Brandenburg, and the number of dependently employed migrants in social insurance (SV-employed), the stagnating rates of business registrations are striking (see Graph. 4).

Graph 4.

Polish citizens, SV-employed and business registrations by Poles in Brandenburg, 2010-2016.



Source: Statistical yearbooks Brandenburg 2011-2017, Gewerbeanzeigen in Brandenburg 2010-2016.

Comparing the number of registrations by citizens from Poland with those by Turkish citizens, and new accession immigrants from Bulgaria and Romania, we see that Polish entrepreneurs no longer dominate the field (Graph 5).

$$
\text { Graph } 5 \text {. }
$$

Business registrations by Polish, Turkish, Bulgarian and Romanian citizens in Brandenburg, 2011-2016.

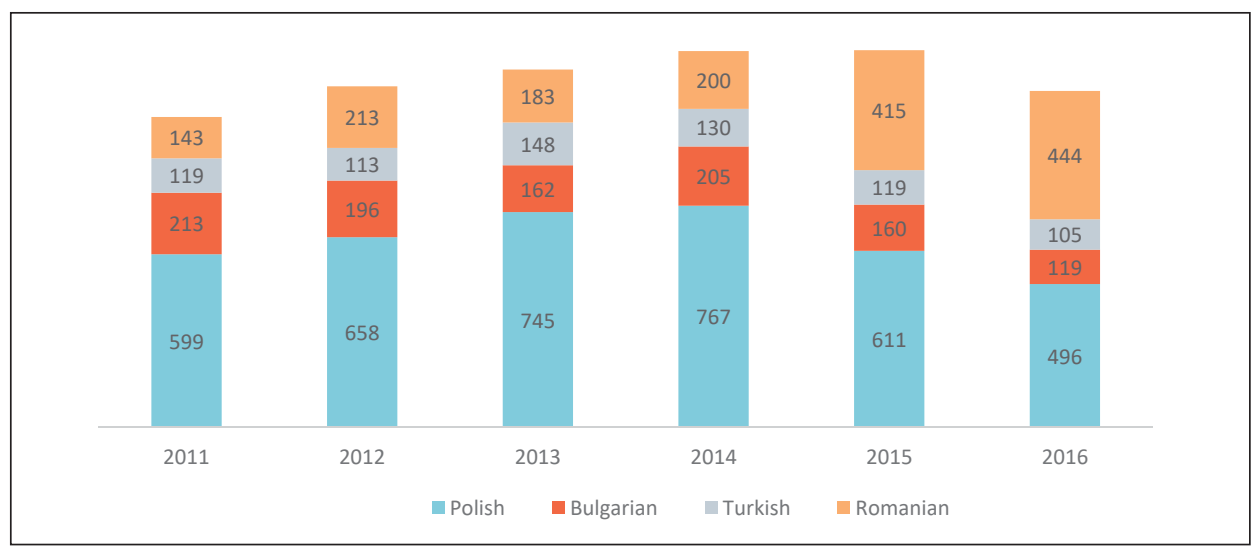

Source: Gewerbeanzeigen in Brandenburg 2011-2016. 
Bulgarians and Romanians are potential competitors for Polish entrepreneurs. Thereby, the number of registrations by Bulgarian citizens are relatively stable, despite that the size of Bulgarian population has more than doubled between 2011 and 2016. The size of the Romanian population tripled in the same period, and there are now three times as many Romanian companies in Brandenburg as in 2011.

In the same period, the decrease of sole proprietorship companies newly registered by German citizens in Brandenburg is considerable (26\% between 2010 and 2016).

The picture looks quite different in Berlin, where the number of companies registered by Polish citizens has been steadily increasing; this increase was the highest in 2011 and 2012 (16.9\% and 19.9\% respectively, comparing to the previous year), thus before the end of the transitional regulations, and it continued at a slower pace in the two following years (Graph 6).

Graph 6 .

Total business registrations by Polish citizens in Berlin, 2010-2017.

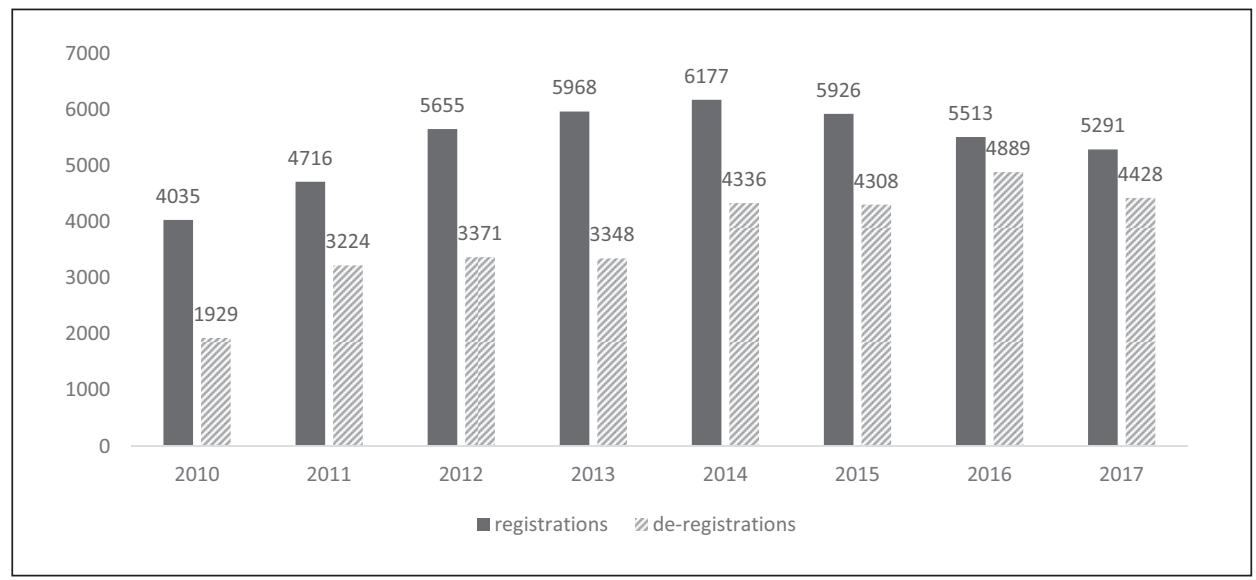

Source: Unternehmen und Arbeitsstätten. Gewerbeanzeigen in den Ländern 2010-2017, own representation.

As Graph 7 demonstrates, the number of employees with Polish citizenship subject to social insurance and working in Berlin increases even stronger than the business registrations and the Polish population in Berlin.

Berlin is Germany's "capital of entrepreneurs". Yet, the number of sole proprietorship companies in Berlin has decreased since 2011. Registrations by Polish citizens have also been decreasing only since 2015 (Graph 7). Unlike in Brandenburg, business registrations by Polish citizens are considerably higher than by Romanian, Bulgarian and Turkish citizens (Graph 8). Registrations by Poles constitute some $15 \%$ of all registrations, and 28\% of registrations by foreign citizens in Berlin in 2017. 
Graph 7 .

Polish citizens, SV-employed and business registrations by Poles in Berlin, 2010-2016

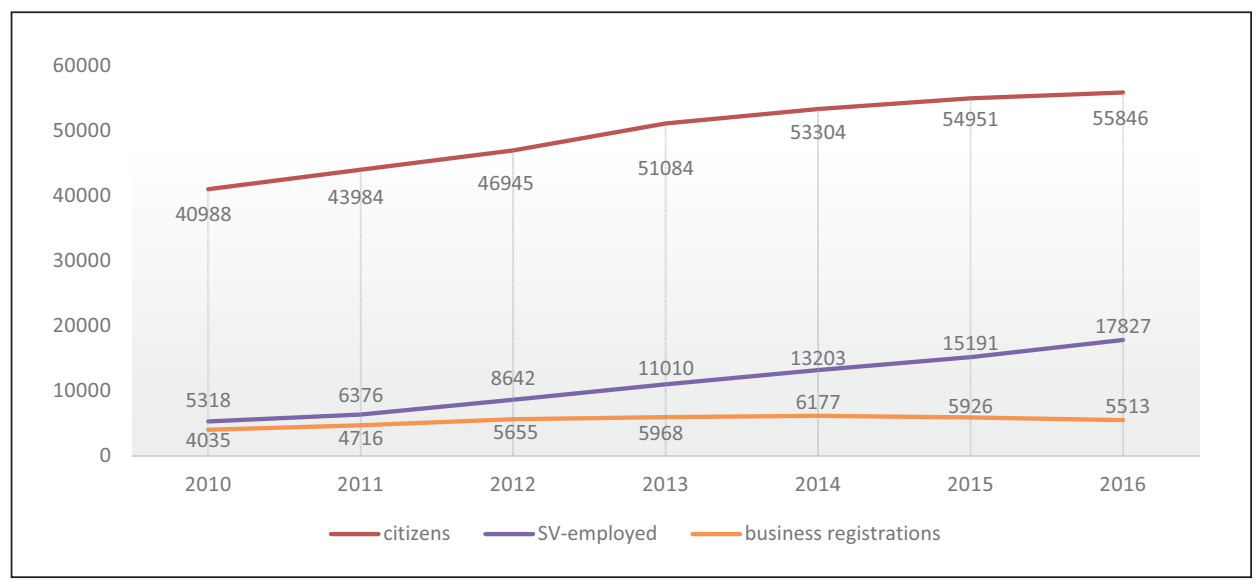

Source: Gewerbeanzeigen in den Ländern 2010-2016, own representation

Graph 8.

Business registrations by Polish, Turkish, Bulgarian and Romanian citizens in Berlin, 2011-2017

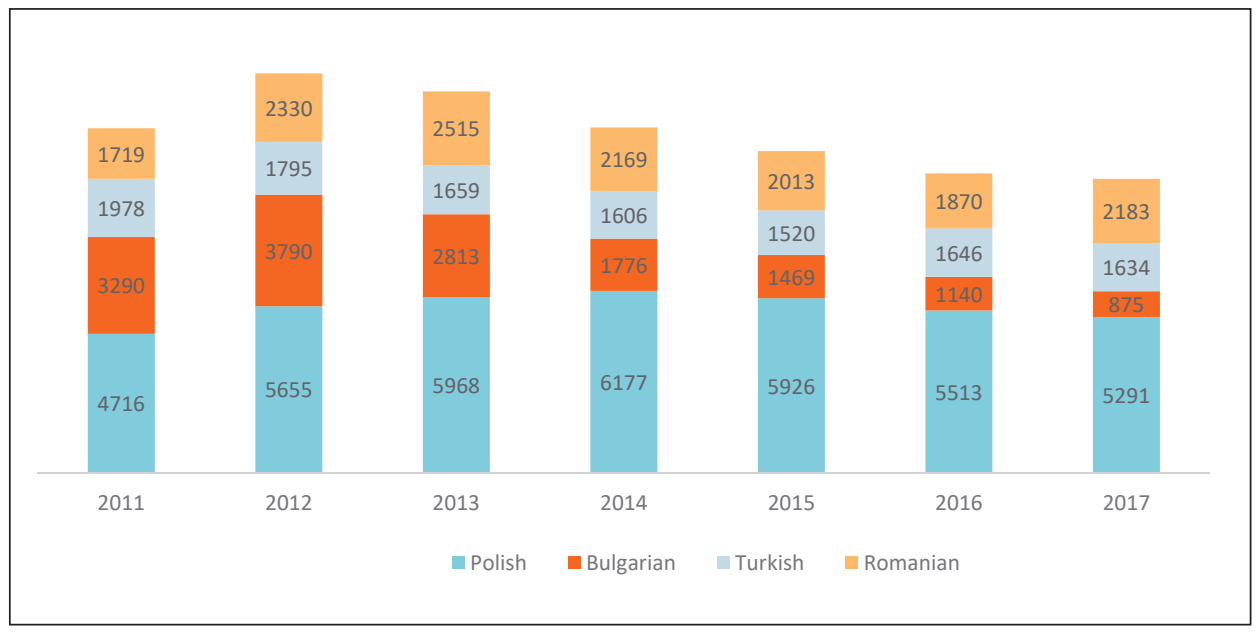

Source: Gewerbeanzeigen in den Ländern 2011-2017, own representation.

\subsection{Polish entrepreneurs in selected sectors of economy}

In terms of sectors of economy in which Poles register their businesses, we see interesting changes over the time. Graph 9 presents the registrations by Polish citizens in Brandenburg in 2010 and 2016 by sector of economy. We see the 
growing differentiation of sectors in which Poles register their companies. In particular, the role of the construction industry is decreasing. While there were 512 companies registered in the construction sector in 2010, their number decreased to 222 in 2016 .

Graph 9.

Registrations by Polish citizens in Brandenburg, 2010 and 2016 by sectors of economy, in \%.

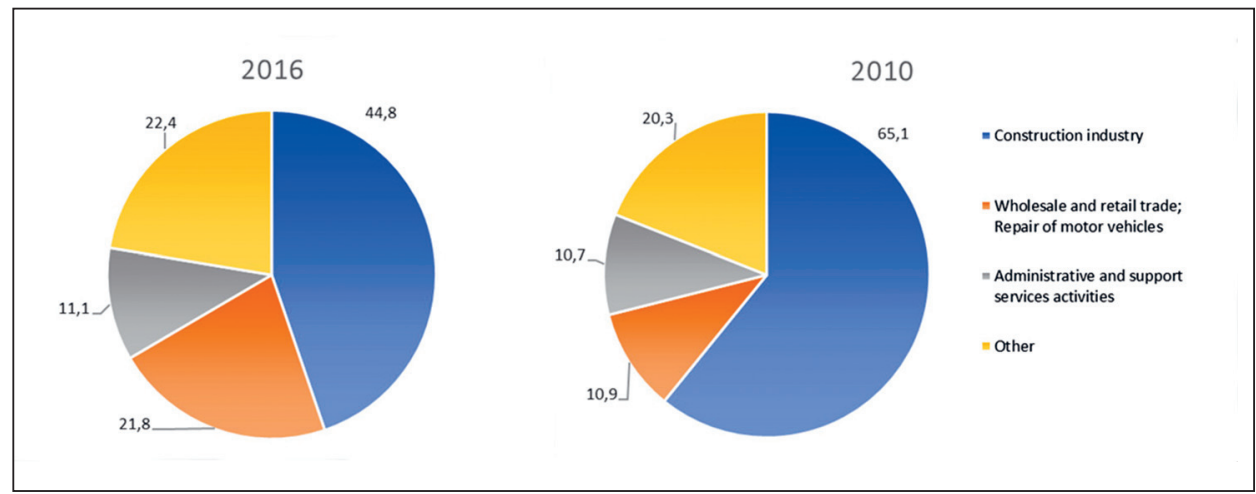

Source: State Statistical Institute Berlin-Brandenburg 2018, own representation.

In Berlin, we see an opposite trend from that in Brandenburg. ${ }^{12}$ Here, the number of companies in the construction industry almost doubled, from 2,415 in 2010 to 4,410 in 2016. In 2016, 80\% of all companies registered in Berlin by Polish citizens were in construction (Graph 9).

Graph 10.

Registrations by Polish citizens in Berlin, 2010 and 2016 by sectors of economy, in \%.

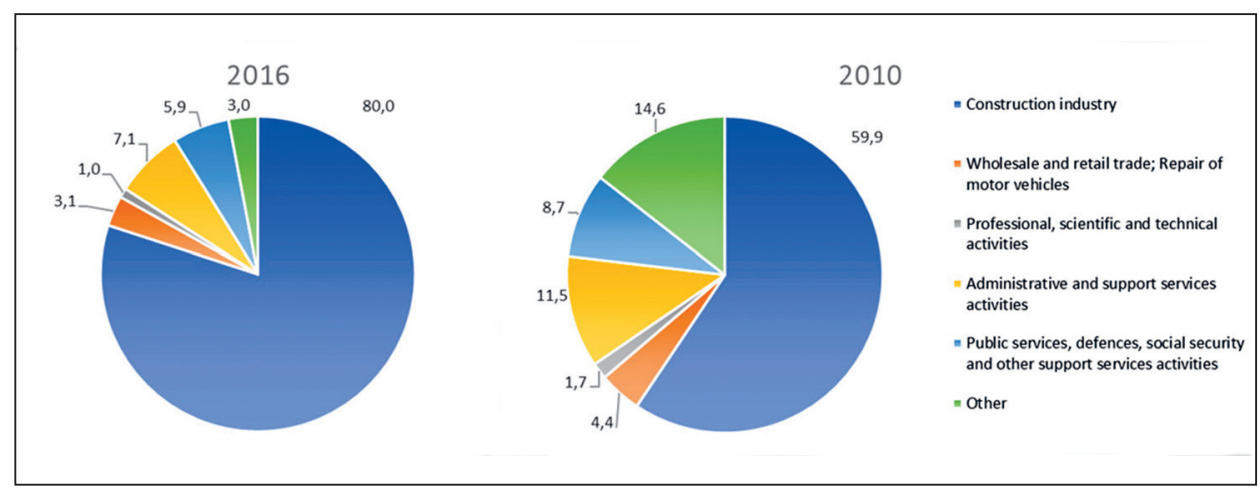

Source: State Statistical Institute Berlin-Brandenburg 2018, own representation. 
In comparison, $21.8 \%$ of all (migrant and non-migrant) business registrations in Berlin in 2018 were in construction (the German average is 13\%). This development reflects two trends: first, the construction industry profits from Berlin's economic growth (Senat Berlin, 2017). Second, out of 8,061 company registrations in this sector, $88.5 \%$ of those were by non-German citizens. Among them, $61.8 \%$ were Polish (4,410 companies). This concentration has two consequences: first, the young, well-educated and innovative (German and foreign) entrepreneurs stand in contrast to a growing group of Eastern European one-man businesses in the low-skilled and low-pay sector whose success is largely dependent on the overall economic condition of the city. Most likely, the boom in construction will continue in Berlin, yet Poles must compete here with even cheaper entrepreneurs from Romania. Second, the expansion of the construction industry leads to a segmentation within the Polish community in Berlin: on the one hand, Berlin attracts welleducated migrants with entrepreneurial ambitions (who are looking for start-up opportunities which they are not yet able to realize); this group is younger and better qualified than elsewhere in Germany (Sachs et al., 2016). This group contrasts with the growing number of one-man construction companies whose presence is well noticeable on Berlin's streets; these recruit labor in Poland, often seasonally. This group is also dominated by men. The third group are women, low-skilled and low-pay workers in feminized occupations such as cleaning, hospitality and catering, social work and care. This increases the gendered pay gap among Polish migrants (Jost and Bogai, 2016).

Further, the sectoral data suggest that Poles in Berlin do not compete with other foreigners in sectors dominated by non-German entrepreneurs, such as hospitality. For example, out of 1,369 companies registered in 2016 in hospitality, 1,336 were owned by non-German citizens, among them 19 Poles. In Brandenburg as well, Poles do not enter the hospitality sector (8 registrations out of 728 total registrations). However, registrations by Poles in the service sector (administrative, technical, health, public services and social security activities), in which foreigners are overrepresented in Berlin, are still low. Only 6.4\% of all registrations in 2016 were made by Poles (19.5\% of registrations by foreigners).

This particular structure of self-employment in Berlin is an outcome of "agglomeration effects": large cities create opportunities for both low- and highly skilled migrants due to demands both for cheap labor and services and by attracting innovation (Yang Liu et al., 2015). However, Polish entrepreneurs obviously do not fully profit from the good prospects for qualified labor in the service sector, but rather by filling the ethnic/migrant niche in the construction sector. This raises the question if Berlin, and to what extent, competes for this type of people with other centres in Europe. We return to this question in the last section of the paper. 


\section{Development of entrepreneurship in Poland}

Looking for some explanation for the increase of business registrations by Polish citizens in Germany, we again turn our attention to Poland. We argue that the propensity towards self-employment among Poles in Germany corresponds to a similar trend in Poland. There are 1.76 million micro enterprises (self-employed and/or employing no more than nine employees) in Poland, which is the absolute majority of all enterprises (99.8\%) (PARP, 2016). Six out of ten employees in the SME sector are self-employed, and their number is increasing. ${ }^{13} 4.7$ million of all people working in the entire enterprise sector were employed in micro- and small enterprise companies (PARP, 2016).

The decreasing number of new business registrations by Polish citizens in Brandenburg and Mecklenburg Western Pomerania since 2014 can be contrasted with the increasing number of business registrations in West Pomeranian and Lubusz voivodships (Graph 11).

Graph 11.

Business registrations in West Pomeranian and Lubusz voivodships, 2001-2017.



Source: Data from KRS (Polish company register), Centre for Business Information online database.

However, self-employment in Poland seems more a necessity than a choice for a large number of workers. Only $43 \%$ of them state to be self-employed through their own preference, while almost half of them see self-employment as an alternative to unemployment. $82 \%$ of the self-employed enjoy being their own boss, but this places Poland in the next to last place among all EU-28 countries (Eurofound, 2017). It is thus possible that self-employment in Germany is considered by Poles as an alternative to unemployment, both in Poland and in Germany.

${ }^{13}$ Data for the second quarter of 2016. Eurostat, Labour Force Survey 2016 and PARP (2016). 
When we have a closer look at the construction sector in Poland, we see on the one hand a great demand for construction workers (there are more job openings than job seekers in almost all occupations) ${ }^{14}$, and rising renumeration per hour, but still the renumeration in West Pomeranian and Lubusz are the lowest in Poland (respectively 15 and 6 PLN net in average, which is less than 4 Euro). The demand for workers is strongest around the Polish metropoles Warsaw and Krakow, and the weakest in Lubusz ${ }^{15}$, and these are further away than Berlin which is also booming (BBB 2018). This demand is met mostly with immigrant workers from Ukraine, while Poles obviously choose to provide their services, as entrepreneurs, in the neighbouring Germany when the minimum wage is currently at 12.20 Euro (for skilled workers in Berlin even 15 Euro). ${ }^{16}$

\section{Concluding remarks: a relational perspective on migrant entrepreneurship in a transnational context}

Conventional scholarship considers migrants' propensity to self-employment in terms of barriers they face to other forms of employment, or the opportunity structures at the local labour markets that give preference to certain ethnic capital. Newer scholarship considers both social and economic embeddedness of migrants, offering an alternative to the focus on ethnic enclave economies. Most recently, a new form of entrepreneurship has been described, a transnational entrepreneurship. This type of businesses involves activities carried out in a cross-national context and initiated by actors who are embedded in at least two different social and economic areas (Drori et al., 2009). Recently, some attention is given to marketrelated factors in two countries, such as saturation (Bagwell, 2018).

Analysing the demographic and economic conditions on both sides of the border in the Polish-German region, and looking at the migration and migrant entrepreneurship patterns, we state that a transnational perspective requires a refined analysis of regional disparities and asymmetries. Country-level data, or even statistics for whole federal states or voivodships, are hardly appropriate to understand the context of regional cross-border migration; macro-level legal and institutional changes also seem to have little impact on entrepreneurial activities of Polish migrants. Geographical proximity allows people to move their houses without changing their lifestyle or job; it also allows them for moving businesses to Germany,

14 Data from Regional Labor Office WUP Zielona Gora, published 2017 at https://www. barometrzawodow.pl.

${ }^{15}$ Online service https://www.wielkiebudowanie.pl.

16 Deutsche Handwerks Zeitung: "Mindestlohn im Baugewerbe steigt zum 1. Januar 2018“, Article published on 19 October 2017 and updated on 4 January 2018, https://www.deutsche-handwerkszeitung.de/zdb-akzeptiert-mindestlohn-regelung-am-bau/150/11266/60857. 
while staying to large extent embedded in Poland. While migrant entrepreneurs we researched do not necessary fit the definition of transnational entrepreneurs, they are transnationally embedded and mobile people. Therefore, it is essential to see developments and trends in both countries in relation to each other.

What we could observe is great flexibility and adaptation of migrants to new conditions, both in terms of residential and entrepreneurial mobility between the countries. The construction sector in urban centres is perhaps the most sensitive to short-term change of demand and supply and thus a good example for such adaptation processes. When we focus Berlin alone, we see that it attracts new entrepreneurs from Poland, yet so far mostly in construction sector which is a classical niche economy with high concentration of immigrants (Waldinger 1995; for a controversy see Rath 2002). At the same time, Berlin is also a large market for commuting migrants in dependent employment in low-paid jobs. Commuters from well-connected locations could be privileged in access to this form of employment. The data suggest thereby a gender division of migrant labor, with self-employment in construction being a domain of male migrants, and care and domestic work of women. But Berlin has also a growing start-up scene which is potentially open to all migrants, thus the picture might change in the future.

On the one hand, we need to consider the future development of migrant entrepreneurship in relation to patterns of residential (im)mobility. Possibly, a larger Polish immigrant community creates opportunities for ethnic businesses, also outside of Berlin. On the other hand, it is possible that Poles residing in Germany will re-establish their businesses in Poland to take advantage of the opportunities for economic growth there. When we consider transnational migrant entrepreneurship in the border region, we must acknowledge that the border matters in terms of constituting two different national frameworks, but it also matters less for how people consider the region as one single transitional space where choice of location is determined by factors other than cultural distance or proximity, than it does for opportunities for business, and for family and personal development.

\section{Acknowledgements}

This publication has been made possible by founding from the German-Polish Science Foundation (Polsko-Niemiecka Fundacja na Rzecz Nauki/Deutsch-Polnische Wissenschaftsstiftung) for the project "Europäisierung der Lebenslagen. Polnische Gründer/innen in Berlin und im Deutsch-Polnischen Grenzgebiet" (2016-2018). 


\section{References}

Amt für Statistik Berlin-Brandenburg (2017) Verfügbares Einkommen in Berlin und Brandenburg liegt bei 88 Prozent des Bundesdurchschnitts: Pressemitteilung Nr. 94.

Anderson J and O'Dowd L (1999) Borders, Border Regions and Territoriality: Contradictory Meanings, Changing Significance. Regional Studies 33(7): 593-604.

Bagwell S (2018) From mixed embeddedness to transnational mixed embeddedness. International Journal of Entrepreneurial Behavior \& Research 24(1): 104-120.

Bates T (1998) Race, self-employment, and upward mobility: An illusive American dream. Baltimore and London: The Woodrow Wilson Center Press.

BBB (2018): Die Bauindustrie Berlin-Brandenburg. Verbandsbericht 2017. Berlin. Online verfügbar unter https://www.bauindustrie-bb.de/fileadmin/share/Material/Aktuelles/Aktuelles_2018/2018_05_17_BauindustrieverbandBB_Verbandsbericht_WEB.pdf.

Błachut B, Cierpiał-Wolan M, Czudec A, Ślusarz G and Noga A (2015) Obszary transgraniczne Polski, Słowacji i Ukrainy- czynniki progresji i peryferyzacji. Rzeszów: Urząd Statystyczny.

Bonacich E (1973) Theory of Middleman Minorities. American Sociological Review, 38: 583-594.

Borjas GJ (1990) Friends or strangers: The impact of immigrants on the US economy. New York: Basic Books.

Brzozowski J (2011) Analiza wplywu powrotów z emigracji na rozwój społeczno-gospodarczy województwa śląskiego. Kraków.

Clark K and Drinkwater S (2000) Pushed out or pulled in? Self-employment among ethnic minorities in England and Wales. Labour Economics 7(5): 603-628.

Drori I, Honig B and Wright M (2009) Transnational Entrepreneurship: An Emergent Field of Study. Entrepreneurship Theory and Practice 33(5): 1001-1022.

Eurofound (2017) Exploring self-employment in the European Union. Luxembourg.

Eurostat (2016) Statistics on commuting patterns at regional level.

Fritsch M, Sorgner A and Wyrwich M (2015) Die Entwicklung der Wirtschaft in Ostdeutschland nach der Wiedervereinigung. GWP - Gesellschaft. Wirtschaft. Politik 64(2): 225-238.

Glick Schiller N, Basch L and Blanc CS (1995) From Immigrant to Transmigrant: Theorizing Transnational Migration. Anthropological Quarterly 68(1): 48-63.

Glorius B (2007) Transnationale Perspektiven: Eine Studie zur Migration zwischen Polen und Deutschland. Zugl.: Halle, Univ., Nat. Fak. III, Diss., 2006 u.d.T.: Glorius, Birgit: Polnische Migranten in Leipzig. Bielefeld: Transcript-Verlag.

Goebel D and Pries L (2006) Transnationalismus oder ethnische Mobilitätsfalle? Das Beispiel des „ethnischen Unternehmertums. In: Kreutzer F and Roth S (eds) Transnationale Karrieren. Wiesbaden: VS Verlag für Sozialwissenschaften, pp. 260-282.

Granovetter M (1995) The Economic Sociology of Firms and Entrepreneur. In: Portes A (ed.) The economic sociology of immigration: Essays on networks, ethnicity, and entrepreneurship. New York: Russell Sage Foundation, pp. 128-165.

GUS (2017) Higher Education Institutions and their Finances in 2016. Warszawa.

Inachin KT (2008) Die Geschichte Pommerns. Rostock: Hinstorff.

Jost O and Bogai D (2016) Ausländer am Arbeitsmarkt in Berlin-Brandenburg: IAB-Regional $1 / 2016$.

Kloosterman R and Rath J (2001) Immigrant entrepreneurs in advanced economies: Mixed embeddedness further explored. Journal of Ethnic and Migration Studies 27(2): 189-201.

Krätke S (1999) Regional Integration or Fragmentation? The German-Polish Border Region in a New Europe. Regional Studies 33(7): 631-641. 
Łada A and Segeš Frelak J (2012) Analyse: Die neue polnische Migration nach Deutschland aus lokaler Perspektive.

Łada A and Segeš Frelak J (2012) Znikająca granica, nowa polska migracja do Niemiec - perspektywa lokalna. Warszawa.

Light I (1987) Unternehmer und Unternehmertum ethnischer Gruppen. In: Heinemann K (ed.) Soziologie wirtschaftlichen Handelns. Opladen: Westdeutscher Verlag, pp. 193-215.

Light I (2007) Global Entrepreneurship and Transnationalism. In: Dana L-P (ed.) Handbook of Research on Ethnic Minority Entrepreneurship: Edward Elgar Publishing.

Leicht R and Langhauser M (2014) Bedeutung und Leistungspotenziale von Migrantenunternehmen in Deutschland. Berlin.

Light I and Rosenstein C (1995) Race, ethnicity, and entrepreneurship in urban America. New York: Aldine De Gruyter.

Light IH and Gold SJ (2008) Ethnic economies. Bingley: Emerald.

Leicht R, Berwig S, Philipp R, Block N, Rüffler N and Ahrens J-P (2017) Gründungspotenziale von Menschen mit ausländischen Wurzeln: Entwicklungen, Erfolgsfaktoren, Hemmnisse. Mannheim: Ifm/Universität Mannheim.

Maack K, Grundmann M, Kreft J, Lewandowska A and Voß E (2004) Wachstumspol und Auswirkungen auf die Entwicklung der deutsch-polnischen Beziehungen. Düsseldorf: HansBöckler-Stiftung.

Matkowska M (2013) Emigracja $z$ województwa zachodniopomorskiego w świetle Narodowego Spisu Powszechnego 2011 roku: WNEiZ Studia i Prace Wydziału Nauk Ekonomicznych i Zarządzania $\mathrm{Nr} 33$.

Miera F (2008) Transnational Strategies of Polish Migrant Entrepreneurs in Trade and Small Business in Berlin. Journal of Ethnic and Migration Studies 34(5): 753-770.

Migrationsbericht 2015 Migrationsbericht 2015. Nürnberg: Bundesamt für Migration und Flüchtlinge.

Nawojczyk M (2009) Przedsiębiorczość: O trudnościach w aplikacji teorii. Kraków: Nomos.

Nee V and Sanders J (2001) Understanding the diversity of immigrant incorporation: a formsof-capital model. Ethnic and Racial Studies 24(3): 386-411.

Nestorowicz J, Kaczmarczyk P, Janicka A and Fihel A (2015) Free movement of workers and transitional arrangements: lessons from the 2004 and 2007 enlargements. Warszawa.

Niemann-Ahrendt K (2017) Die Anziehungskraft Berlins: Wanderungsdaten aus dem Einwohnermelderegister. Zeitschrift für amtliche Statistik Berlin Brandenburg 4.

Nowicka M (2007) Von Polen nach Deutschland und zurück: Die Arbeitsmigration und ihre Herausforderungen für Europa. Bielefeld: Transcript Verlag.

O’Dowd L (2002) The Changing Significance of European Borders. Regional \& Federal Studies 12(4): 13-36.

Opiłowska E (2015a) Granica państwowa / pogranicze. In: Pletzing C (ed.) Interakcje: Leksykon komunikowania polsko-niemieckiego. Wroclaw: Atut, pp. 201-211.

Opiłowska E (2015b) Microcosm of European Integration: The German-Polish border regions in transformation. Baden-Baden: Nomos.

Paffhausen J (2016) Bevölkerungsentwicklung im Land Brandenburg 2015: Wie hat sich das gegenwärtige Migrationsgeschehen ausgewirkt? Zeitschrift für amtliche Statistik Berlin Brandenburg 3.

Palenga-Möllenbeck E (2014) Pendelmigration aus Oberschlesien: Lebensgeschichten in einer transnationalen Region Europas. Bielefeld: Transcript Verlag.

PARP (2016) Raport o stanie sektora MSP w Polsce. Warszawa. 
Piskorski JM (1999) Pommern im Wandel der Zeiten. Szczecin: Zamek Książąt Pomorskich.

Portes A (2003) Conclusion: Theoretical Convergencies and Empirical Evidence in the Study of Immigrant Transnationalism. International Migration Review 37(3): 874-892.

Portes A and Bach R (1985) Latin Journey: Cuban and Mexican Immigrants in the United States. Berkeley.

Portes A, Guarnizo LE and Haller WJ (2002) Transnational Entrepreneurs: An Alternative Form of Immigrant Economic Adaptation. American Sociological Review 67(2): 278.

Pries L (2000) „Transmigranten“ als ein Typ von Arbeitswanderern in pluri-lokalen sozialen Räumen. In: Gogolin I and Nauck B (eds) Migration, gesellschaftliche Differenzierung und Bildung: Resultate des Forschungsschwerpunktprogramms FABER. Wiesbaden: VS Verlag für Sozialwissenschaften, pp. 415-437.

Razin E (2002) Conclusion The economic context, embeddedness and immigrant entrepreneurs. International Journal of Entrepreneurial Behavior \& Research 8(1/2): 162-167.

Reichert-Schick A (2010) Auswirkungen des demographischen Wandels in regionaler Differenzierung: Gemeinsamkeiten und Gegensätze ländlich-peripherer Entleerungsregionen in Deutschland - die Beispiele Vorpommern und Westeifel. Raumforschung und Raumordnung 68(3): 153-168.

Rath J (2002) A quintessential immigrant niche? The non-case of immigrants in the Dutch construction industry. Entrepreneurship \& Regional Development 14 (4): 355-372.

Sachs A, Hoch M, Münch C and Steidle H (2016) Migrantenunternehmen in Deutschland zwischen 2005 und 2014. Gütersloh.

Sanders J and Nee V (1996) Immigrant Self-Employment: The Family as Social Capital and the Value of Human Capital. American Sociological Review, 61(2): 231-249.

Senat Berlin (2017) Wirtschafts- und Innovationsbericht Berlin 2016/2017. Berlin.

UStat (2014) Migracje zagraniczne i wewnętrzne ludności województwa lubuskiego: Narodowy Spis Powszechny Ludności i Mieszkań 2011. Zielona Góra.

van Delft H, Gorter C and Nijkamp P (2000) In Search of Ethnic Entrepreneurship Opportunities in the City: A Comparative Policy Study. Environment and Planning C: Government and Policy 18(4): 429-451.

van Houtum H (2000) III European perspectives on borderlands. Journal of Borderlands Studies 15(1): 56-83.

Vogler-Ludwig K, Düll N and Kriechel B (2014) 2015 Arbeitsmarkt 2030 - Die Bedeutung der Zuwanderung für Beschäftigung und Wachstum. Bielefeld.

Waldinger RD (1995) The "other side" of embeddedness. A case-study of the interplay of economy and ethnicity. Ethnic and Racial Studies 18(3): 555-580.

Waldinger RD, Aldrich H and Ward R (2006a) Ethnic entrepreneurs: Immigrant business in industrial societies. Newbury Park, CA: Sage Publications.

Waldinger RD, Aldrich H and Ward R (2006b) Opportunities, Group Characteristics and Strategies. In: Waldinger RD, Aldrich $\mathrm{H}$ and Ward R (eds) Ethnic entrepreneurs: Immigrant business in industrial societies. Newbury Park, CA: Sage Publications, pp. 13-49.

Yang Liu C, Painter G and Wang Q (2015) Immigrant entrepreneurship and agglomeration in high-tech industries in the USA. In: Karlsson C, Gråsjö U and Wixe S (eds) Innovation and entrepreneurship in the global economy: Knowledge, technology and internationalization. Cheltenham, UK, Northampton, MA, USA: Edward Elgar Publishing, pp. 184-209. 